\title{
Assessment of the Effects of Cocoa Powder on Blood Pressure in Humans - A Preliminary Study in Osogbo
}

\author{
*Alebiosu C.O. ${ }^{1}$, Omobuwa O. ${ }^{2}$, Akintunde A.A ${ }^{3}$, Peter J.O ${ }^{4}$, Olaniyan O.O
}

\begin{abstract}
Background: Cocoa powder contains polyphenols (phytonutrients) which are increasingly being used either as dietary supplements or in fortification of foods. Polyphenols exhibit antioxidant activity known to play a vital role in reducing the risk of some diseases (including cardiovascular diseases) in humans by protecting cells in the body from damage during aerobic production of energy. The aim of this study was to investigate the effect of flavonoid-rich Cocoa powder on the blood pressure of clinically stable hypertensive patients.

Materials and Methods: In this intervention study, sixty-eight patients attending cardiology clinics (for treatment of hypertension) in two selected hospitals were serially recruited into the study after ethical approval had been obtained. Physical examination was conducted and selected parameters (including blood pressure, weight and height) were recorded. Each participant was instructed to consume $25 \mathrm{~g}$ of cocoa powder diluted in $250 \mathrm{ml}$ of water twice daily. Physical examinations were repeated on a 2-weekly basis, BMI was calculated on each visit. They were followed up for 9 weeks and the relevant clinical parameters were repeated at each clinic visit.

Results: Of the 67 subjects examined on the first day, 18 (26.8\%) were hypertensive (BP $>140 / 90 \mathrm{mmHg}$ ). During subsequent visits, the proportion of hypertensive BP status gradually declined over the weeks as follows: 19 out of 67 (28.4\%), 16 out of 63 (25.4\%), 8 out of $60(13.3 \%)$ and 7 out of 60 (11.6) in weeks 3, 5, 7 and 9 respectively. The BMI of the subjects did not show any significant variation over the weeks during the course of the study.

Conclusion: The study showed that daily cocoa consumption may be beneficial in the control of the BP and complimentary to pharmacotherapy in Nigerian hypertensive patients. However, we recommend the conduct of further studies (randomized study on a larger scale) in the Nigerian population in order to further validate the findings of this study.
\end{abstract}

Keywords: Cocoa powder, blood pressure, hypertensives.

\author{
*Corresponding Author \\ Alebiosu C.O. \\ http://orcid.org/0000-0001-6224-6039 \\ E-mail: olutayo.alebiosu@uniosun.edu.ng
}

${ }^{1}$ Department of Medicine, College of Health Sciences, Osun State University. ${ }^{2}$ Department of Community Medicine,
College of Health Sciences, Osun State University. ${ }^{3}$ Department of Medicine, Faculty of Clinical Sciences,
College of Health Sciences, Ladoke Akintola University of Technology, (LAUTECH), Osogbo, Nigeria
${ }^{4}$ Department of Medicine, College of Health Sciences, LAUTECH Teaching Hospital, Osogbo.
${ }^{5}$ Chemical Pathology Laboratory, College of Health Sciences, Osun State University, Osogbo.

Received: July 12, 2020

Accepted: September 9, 2020

Published: September 30, 2020

Research Journal of Health Sciences subscribed to terms and conditions of Open Access publication. Articles are distributed under the terms of Creative Commons Licence (CC BY-NC-ND 4.0). (http://creativecommons.org/licences/by-nc-nd/4.0).

https://dx.doi.org/10.4314/rejhs.v8i3.5 


\title{
Évaluation des effets de la poudre de cacao sur la pression artérielle chez l'homme-une étude préliminaire à Osogbo
}

\author{
*Alebiosu C.O. ${ }^{1}$, Omobuwa O. ${ }^{2}$, Akintunde A.A ${ }^{3}$, Peter J.O ${ }^{4}$, Olaniyan O.O
}

\section{Résumé}

Contexte général de l'étude : La poudre de cacao contient des poly phénols (phytonutriments) qui sont de plus en plus utilisés comme compléments alimentaires ou pour enrichir les aliments. Les poly phénols présentent une activité antioxydant connue pour jouer un rôle essentiel dans la réduction du risque de certaines maladies (y compris les maladies cardiovasculaires) chez l'homme en protégeant les cellules du corps contre les dommages lors de la production aérobie d'énergie.

Matériaux et méthodes de l'étude : Soixante-huit patients fréquentant des cliniques de cardiologie (pour le traitement de l'hypertension) dans 2 hôpitaux sélectionnés à Osogbo ont été recrutés en série dans l'étude. Un examen physique a été effectué sur eux et certains paramètres (y compris la pression artérielle, le poids et la taille) ont été enregistrés. Chaque participant a été invité à consommer $25 \mathrm{~g}$ de poudre de cacao diluée dans 250 $\mathrm{ml}$ d'eau deux fois par jour. Les examens physiques ont été répétés toutes les deux semaines, l'IMC a également été calculé à chaque visite. Ils ont été suivis pendant 9 semaines et les paramètres cliniques pertinents ont été répétés à chaque visite

Résultats de l'étude : Sur les 67 sujets examinés le premier jour, 18 (28,5\%) étaient hypertendus (TA> 140/90 $\mathrm{mmHg}$ ). Lors des visites ultérieures, la proportion d'hypertension artérielle a progressivement diminué au fil des semaines comme suit: $19(28,4 \%), 16(25,4 \%), 8(13,3 \%)$ et $7(11,6)$ au cours des semaines 3, 5, 7 et 9 respectivement. L'IMC des sujets n'a pas montré de variation significative au cours des semaines au cours de l'étude

Conclusion: L'étude a montré que la consommation quotidienne de cacao peut être bénéfique pour le contrôle de la TA et complémentaire à la pharmacothérapie chez les patients hypertendus nigérians. Cependant, nous recommandons la conduite d'études complémentaires (étude randomisée à plus grande échelle) dans la population nigériane afin de valider davantage les résultats de cette étude.

Mots-clés : Poudre de cacao, tension artérielle, hypertendu

\section{*Corresponding Author}

Alebiosu C.O.

http://orcid.org/0000-0001-6224-6039

E-mail: olutayo.alebiosu@uniosun.edu.ng

\footnotetext{
${ }^{1}$ Department of Medicine, College of Health Sciences, Osun State University. ${ }^{2}$ Department of Community Medicine, College of Health Sciences, Osun State University. ${ }^{3}$ Department of Medicine, Faculty of Clinical Sciences, College of Health Sciences, Ladoke Akintola University of Technology, (LAUTECH), Osogbo, Nigeria ${ }^{4}$ Department of Medicine, College of Health Sciences, LAUTECH Teaching Hospital, Osogbo. ${ }^{5}$ Chemical Pathology Laboratory, College of Health Sciences, Osun State University, Osogbo.
} 


\section{INTRODUCTION}

Cocoa powder (CP) is the major ingredient of cocoa based beverages and confectioneries throughout the world. CP contains a good quantity of metabolizable carbohydrate, a high proportion of dietary fiber of up to $30 \%$ and minerals among which potassium and sodium are of primary importance (Assa et al., 2019). CP contains polyphenols which are phytonutrients and are sometimes referred to as phytochemicals or nutraceuticals which are increasingly being used as dietary supplements or in fortification of foods (Assa et al., 2019). Polyphenols exhibit antioxidant activity, which has been reported to play a vital role in reducing the risk of some diseases in humans by protecting cells in the body from damage during aerobic production of energy. Polyphenols are also thought to reduce the risk cardiovascular diseases, inhibit the formation of low-density lipoproteins (LDL), cholesterol, and modulate immune functions (Wollgast \& Anklam, 2000). Cocoa is a rich source of flavonoids particularly flavanols and procyanidins. $\mathrm{CP}$ contains flavonols which are natural compounds in cocoa that may modulate platelet in the process reducing blood clot risks (Katz et al. 2011). This has been increasingly linked to promising circulatory benefits including improved blood flow and a reduced tendency to form damaging clots. However, the preservation of polyphenols during the processing of cocoa is important in order for it to be able to exhibit the health effects associated with cocoa consumption. In Nigeria, where the costs of diabetes and hypertension care are borne almost entirely by the patients, coupled with suboptimal drug compliance with resultant poor control, cost effective and affordable approaches are needed to meet this challenge.

Nigeria bears a double burden of disease because despite the fact that she is still battling with the scourge of communicable diseases, she is now also saddled with life-style related noncommunicable diseases (NCDs) that accompany industrialization and urbanization.

The Nigerian National Non-Communicable Disease Survey in 1997 reported an adult national hypertension prevalence of $11.4 \%$; being $14.8 \%$ and $9.8 \%$ in urban and rural areas, respectively. This would have been higher if the new cutoff value of $140 / 90 \mathrm{mmHg}$ was used instead of $160 / 95 \mathrm{mmHg}$. The prevalence of hypertension in both rural and urban communities in Nigeria is increasing. Various community surveys in Nigeria have shown an adult prevalence of $15 \%-36.6 \%$. (Oladapo et al, 2010) recently reported a prevalence of $20.8 \%$ in the rural community of Egbeda, South-west Nigeria. The prevalence in semi-urban Ile-Ife was $36.6 \%$, while that in Ipetumodu, Osun State, was $26.4 \%$ for mild hypertension ( $\mathrm{BP} \geq 140 / 90 \mathrm{mmHg}$ ) and $11.8 \%$ for moderate hypertension (BP $\geq 160 / 100 \mathrm{mmHg}$ ). The overall prevalence of hypertension ranges from $14.5 \%$ in Nigeria, $16.9 \%$ in Cameroon, $28.7 \%$ in Accra, to $32.6 \%$ for blacks in the United States. Cross-migration from rural to urban areas and vice versa, the asymptomatic nature of the disease, changing lifestyles, and the environment are contributing to the rising problem of hypertension. Hypertension has been associated with various factors, including age, gender, family history, alcohol consumption, smoking, obesity, level of education, and occupation (Kapoor et al. 2010). Observational studies have shown that lifestyle changes including physical activity, weight loss, and diet can prevent hypertension and the complications (Knowler et al., 2002). Prevention (primary and secondary) of this disease and its complications through life style modifications is highly desirable.

This study therefore set out to investigate the effect of flavonoid-rich Cocoa powder on the blood pressure of clinically stable hypertensive patients.

\section{METHODOLOGY}

This quasi-experimental (intervention) study was carried out at the cardiology clinics of the Ladoke Akintola University of Technology Teaching Hospital (LAUTH) and the State Hospital, Asubiaro; both in Osogbo, Osun State.

The study population comprised of individuals already diagnosed with hypertension and attending the cardiology clinics of the selected hospitals (for treatment of hypertension). Eligible participants were serially recruited into the study and a total of 68 subjects were enrolled for the study. Institutional ethical approval was obtained from both the ethical committee of LAUTECH Teaching Hospital, Osogbo and the State Specialist Hospital, Asubiaro, Osogbo, Nigeria. The study was conducted between September and November 2019. Written informed consent was also obtained from each individual participant. Participation was completely voluntary and confidentiality of all information obtained from the subjects was assured.

The inclusion criteria for recruiting subjects into the study are as stated:

a) individuals previously diagnosed with 
hypertension and were already on treatment for at least six months

b) individuals who met the above criterion and were not engaged in regular daily intake of any cocoa-based beverage.

The following are the criteria for excluding individuals from participating in the study:

c) newly diagnosed hypertensive patients (first timers at the clinics)

d) previously diagnosed hypertensive patients who regularly consumed cocoa-based beverages.

All the subjects had baseline physical examination done on them and medication(s) being taken were documented. Blood samples were taken for laboratory investigations at first contact to serve as baseline parameters of the respondents. Hypertension was defined as systolic blood pressure of $\geq 140 \mathrm{mmHg}$ and/or diastolic blood pressure of $\geq 90$ $\mathrm{mmHg}$. Parameters, including age, sex, drug therapy, weight, height, and blood pressure, were obtained and BMI for each respondent was calculated as the ratio of weight (kilograms) to height (metres) squared $\left(\mathrm{kg} / \mathrm{m}^{2}\right)$.

The respondents each received packets of flavonol-rich cocoa powder (Oluji pure cocoa powder) and were trained to prepare and consume $50 \mathrm{~g}$ of the cocoa powder daily (consumed as $25 \mathrm{mg}$ diluted in $250 \mathrm{mls}$ of water twice daily) while the study lasted.

The main study instrument was a semistructured, interviewer-administered questionnaire which collected information on respondents' sociodemographics, medical history, social history and physical activity as well a section for recording the results of their physical examination (blood pressure, weight, height, BMI). Accoson mercury sphygmomanometer was used to measure the BP in $\mathrm{mmHg}$, a clinic-stationed stadiometer was used for measuring height while a standardized bathroom weighing scale was used to take the weight of the study respondents. Data were analyzed using Statistical Package for Service Solutions (SPSS) version 23. Data were summarized as frequencies and percentages for qualitative variables and mean (standard deviation) for some quantitative variables. Univariate and bivariate analyses were done and results were presented using tables.

\section{RESULTS}

Sixty-eight respondents participated in the study and they were aged between 35 and 79 years of which nearly two-thirds (63.2\%) were females. Majority of the respondents were Christians (72.1\%) and most $(95.6 \%)$ of them of the Yoruba ethnic group. Fiftynine $(86.8 \%)$ of the respondents were married and nearly three-fifths $(57.4 \%)$ had tertiary education. About two-fifths (41.2\%) of the respondents were civil servants while 18 of them $(26.5 \%)$ were selfemployed; $6(8.8 \%)$ were retirees while $9(13.2 \%)$ professionals and only 1 of them $(1.5 \%)$ was unemployed.

Majority $(83.8 \%)$ of the study respondents owned their residence while $57.4 \%$ of them had at least one vehicle (car, truck or van). Sixty-eight respondents (45.6\%) earned between 18,000 and 50,000 naira while $23(33.8 \%)$ of them earned more than $\$ 50,000.00$. (Table 1)

Majority $(73.5 \%)$ of the respondents were diagnosed of hypertension within 10 years preceding the study while only four of them $(5.9 \%)$ had their diagnosis made 30 or more years ago. Most of the respondents had already been placed on antihypertensive medications (for a variable length of duration) as at the time of this study; only one (1.5\%) of them had ever had a stroke; 10 of them had arthritis while 1 of them had diabetes mellitus. (Table 2A). Thirty-nine (57.4\%) of the study participants were on calcium channel blockers, $26(38.2 \%)$ were on Angiotensin converting enzyme inhibitors (ACE-I) inhibitors and $16(23.5 \%)$ were on diuretics. (Table 2B).

Most of the respondents (88.2\%) had never smoked tobacco; $20.6 \%$ agreed that they were currently taking alcoholic beverages. All but one of the respondents engaged in one form or another of physical exercise (of varying frequencies); briskwalking was the most common $(86.7 \%)$ form of exercise that the respondents engaged in, although only $55.8 \%$ of them spent at least 15 minutes on daily physical exercise. (Table 3 ).

Of the 67 respondents who submitted themselves to physical examination on the first day of the study, $18(26.5 \%)$ had their BP in the hypertensive range while the remaining $49(73.5 \%)$ were normotensive. When the BMIs of the study participants were calculated on the same day, 13 $(19.4 \%)$ of them had their BMI in the healthy range of values, $25(37.3 \%)$ were overweight, 25 (37.3\%) 
were obese and $4(6.0 \%)$ were morbidly obese. (Table 4).

During subsequent visits, the proportion of hypertensive BP status gradually declined over the weeks as follows: $19(28.4 \%), 16(25.4 \%), 8(13.3 \%)$ and 7 (11.6) in weeks 3, 5, 7 and 9 respectively. The BMI of the subjects did not show any significant variation over the weeks during the course of the study. Table 5.

Table 6 shows that at recruitment, most of the respondents had their serum lipid and glucose profiles within normal limits but only 21 (31.3\%) of them had their high-density lipoprotein being with normal values.

Table 1A: Socio-demographic information of the study respondents $(\mathrm{n}=68)$

\begin{tabular}{|c|c|c|}
\hline Variables & Frequency & Percentage (\%) \\
\hline \multicolumn{3}{|l|}{ Age } \\
\hline Young adults $(\leq 39$ years $)$ & 9 & 13.2 \\
\hline $\begin{array}{l}\text { Middle aged adults ( } 40-59 \\
\text { years) }\end{array}$ & 30 & 44.1 \\
\hline Old adults ( $\geq 60$ years $)$ & 29 & 42.6 \\
\hline \multicolumn{3}{|l|}{ Sex } \\
\hline Male & 25 & 36.8 \\
\hline Female & 43 & 63.2 \\
\hline \multicolumn{3}{|l|}{ Religion } \\
\hline Christianity & 49 & 72.1 \\
\hline Islam & 19 & 27.9 \\
\hline \multicolumn{3}{|l|}{ Ethnicity } \\
\hline Yoruba & 65 & 95.6 \\
\hline Igbo & 3 & 4.4 \\
\hline \multicolumn{3}{|l|}{ Marital status } \\
\hline Single & 1 & 1.5 \\
\hline Married & 59 & 86.8 \\
\hline Separated & 1 & 1.5 \\
\hline Widowed & 7 & 10.3 \\
\hline \multicolumn{3}{|l|}{ Level of education } \\
\hline No formal education & 5 & 7.4 \\
\hline $\begin{array}{l}\text { Completed primary } \\
\text { education/Standard six }\end{array}$ & 13 & 19.1 \\
\hline $\begin{array}{l}\text { Completed secondary } \\
\text { education }\end{array}$ & 11 & 16.2 \\
\hline Tertiary education & 39 & 57.4 \\
\hline \multicolumn{3}{|l|}{ Spouse's level of education } \\
\hline No formal education & 2 & 2.9 \\
\hline $\begin{array}{l}\text { Completed primary } \\
\text { education/Standard six }\end{array}$ & 11 & 16.2 \\
\hline $\begin{array}{l}\text { Completed secondary } \\
\text { education }\end{array}$ & 12 & 17.6 \\
\hline Tertiary education & 42 & 61.8 \\
\hline Not applicable & 1 & 1.5 \\
\hline \multicolumn{3}{|l|}{ Occupation } \\
\hline Artisan & 6 & 8.8 \\
\hline Civil servant & 28 & 41.2 \\
\hline Self-employed & 18 & 26.5 \\
\hline Unemployed & 1 & 1.5 \\
\hline Professionals & 9 & 13.2 \\
\hline Retiree & 6 & 8.8 \\
\hline Others & 3 & 4.4 \\
\hline
\end{tabular}


Table 1B: Other socio-demographic information of the study respondents $(\mathrm{n}=68)$

\begin{tabular}{|c|c|c|}
\hline Variables & Frequency & Percentage (\%) \\
\hline \multicolumn{3}{|l|}{ Type of housing (A) } \\
\hline Rented & 11 & 16.2 \\
\hline Owner (landlord/landlady) & 57 & 83.8 \\
\hline \multicolumn{3}{|l|}{ Type of housing (B) } \\
\hline Duplex & 2 & 2.9 \\
\hline 3-bedroom flat & 50 & 73.5 \\
\hline 2-bedroom flat & 12 & 17.6 \\
\hline Room and parlour & 2 & 2.9 \\
\hline One room & 2 & 2.9 \\
\hline \multicolumn{3}{|l|}{$\begin{array}{l}\text { Does your family have car } \\
\text { (or truck or van)? }\end{array}$} \\
\hline No & 29 & 42.6 \\
\hline Yes, one & 34 & 50.0 \\
\hline Yes, two or more & 5 & 7.4 \\
\hline \multicolumn{3}{|l|}{$\begin{array}{l}\text { Does your family have a } \\
\text { motorcycle? }\end{array}$} \\
\hline No & 63 & 92.6 \\
\hline Yes, one & 4 & 5.9 \\
\hline Yes, two or more & 1 & 1.5 \\
\hline \multicolumn{3}{|l|}{$\begin{array}{l}\text { Average monthly income } \\
\text { (naira) }\end{array}$} \\
\hline$<18000$ & 14 & 20.6 \\
\hline $18000-50000$ & 31 & 45.6 \\
\hline$>50000$ & 23 & 33.8 \\
\hline \multicolumn{3}{|l|}{$\begin{array}{l}\text { Spouse's average monthly } \\
\text { income }(n=49)\end{array}$} \\
\hline$<18000$ & 1 & 1.5 \\
\hline $18000-50000$ & 11 & 16.2 \\
\hline$>50000$ & 12 & 17.6 \\
\hline Don't know & 25 & 36.8 \\
\hline
\end{tabular}

\section{DISCUSSION}

This study found a general reduction in the BP of the study participants during the study period, a finding similar to that of Jumar and Schmieder (2015) who reported a significant lowering effect in hypertensive subjects (systolic BP $>140 / 90 \mathrm{mmHg}$ at baseline) according to their epidemiologic data from different patient cohorts which revealed a significant drop in the office BP and ambulatory BP in hypertensive patients on cocoa flavanol when compared with normotensive individuals as their study reported that "Cocoa flavanol has been shown to lower systolic and diastolic office and ambulatory BP. Even though there is just a modest $\mathrm{BP}$ reduction of $3 \mathrm{~mm} \mathrm{Hg}$ in an average mixed population, patients with hypertension and people younger than 50 years experienced larger effects". The number of normotensive patients consistently increased over the weeks of the study as shown in table 5. The role of age on the BP-lowering effect of cocoa was not be evaluated in this study although, it has been reported that BP-lowering effect of cocoa is attenuated with increasing age (Ried et al., 2012). Ried et al went on to say that Cocoa flavanols had been shown to reduce vascular resistance and arterial stiffness, and are potent scavengers of free radicals (Schroeter, 2006), which may lead to improved vascular function.

Concerning the BMI of the study subjects, there was no significant variation in any direction. This finding is important because it has been recommended that precaution in all products containing chocolate is mandatory because of high caloric load of commercially available chocolate (about $500 \mathrm{kcal} / 100 \mathrm{~g}$ ) and associated weight gain, a risk factor for hypertension, diabetes, and dyslipidemia (Corti et al. 2009). Furthermore, this study is in agreement with previous epidemiological investigations which reported that normotensive and mildly hypertensive patients with daily intake of $50 \mathrm{mg}$ epicatechin revealed a significant reduction in mean arterial systolic and diastolic BP compared with placebo (Hooper et al. 2012, Taubert et al. 2007) 
Table 2A: Medical history of the study respondents $(\mathrm{n}=68)$

\begin{tabular}{|c|c|c|}
\hline Variables & Frequency & Percentage (\%) \\
\hline \multicolumn{3}{|c|}{$\begin{array}{l}\text { When were you diagnosed of hypertension } \\
\text { (years ago)? }\end{array}$} \\
\hline$\leq 10$ years & 50 & 73.5 \\
\hline $11-29$ years & 14 & 20.6 \\
\hline$\geq 30$ years & 4 & 5.9 \\
\hline \multicolumn{3}{|c|}{$\begin{array}{l}\text { For how long have you been taking } \\
\text { antihypertensive medications? }(n=65)\end{array}$} \\
\hline $1-3$ years & 28 & 41.2 \\
\hline $4-6$ years & 8 & 11.8 \\
\hline $7-9$ years & 5 & 7.5 \\
\hline$\geq 10$ years & 21 & 30.9 \\
\hline Not on medications & 3 & 4.4 \\
\hline \multicolumn{3}{|c|}{ Have you ever had a stroke? $(n=68)$} \\
\hline Yes & 1 & 1.5 \\
\hline No & 67 & 98.5 \\
\hline \multicolumn{3}{|c|}{$\begin{array}{l}\text { Have you ever been diagnosed with diabetes } \\
\text { mellitus? }(n=68)\end{array}$} \\
\hline Yes & 1 & 1.5 \\
\hline No & 67 & 98.5 \\
\hline \multicolumn{3}{|c|}{$\begin{array}{l}\text { If yes to above, how long ago were you } \\
\text { diagnosed? }(n=1)\end{array}$} \\
\hline $1-3$ years & 1 & 1.5 \\
\hline \multicolumn{3}{|c|}{$\begin{array}{l}\text { Have you been diagnosed of any other } \\
\text { chronic non-communicable diseases } \\
\text { (diabetes, arthritis, cancer)? }(\mathbf{n}=68)\end{array}$} \\
\hline Yes & 11 & 16.2 \\
\hline No & 57 & 83.8 \\
\hline \multicolumn{3}{|c|}{$\begin{array}{l}\text { If yes to above, state the names of the } \\
\text { diseases }(n=11)\end{array}$} \\
\hline Arthritis & 10 & 90.9 \\
\hline Diabetes mellitus & 1 & 10.1 \\
\hline
\end{tabular}

Table 2B: Medications currently being taken by the respondents $(n=68)$

\begin{tabular}{lll}
\hline Class of Medication* & Frequency & Percentage (\%) \\
\hline $\begin{array}{l}\text { Diuretics (bumetanide, furosemide, torsemide, } \\
\text { hydrochlorothiazide (HCT), indapamide, amiloride) }\end{array}$ & 16 & 23.5 \\
$\begin{array}{l}\text { Calcium channel blockers (amlodipine, clevidipine, } \\
\text { felodipine, nicardipine, nifedipine, nisoldipine, } \\
\text { verapamil) }\end{array}$ & 39 & 57.4 \\
$\begin{array}{l}\text { ACE inhibitors (lisinopril, perindopril, benazepril, } \\
\text { captopril) }\end{array}$ & 26 & 38.2 \\
$\begin{array}{l}\text { Angiotensin II receptor antagonists (azilsartan, } \\
\text { candesartan, valsartan, losartan) }\end{array}$ & 10 & 14.7 \\
$\begin{array}{l}\text { Adrenergic receptor antagonists (acebutolol, } \\
\text { atenolol, carvedilol, nadolol, timolol, doxazosin, } \\
\text { prazosin, carvedilol) }\end{array}$ & 4 & 5.9 \\
$\begin{array}{l}\text { Aldosterone receptor antagonists (eplerenon, } \\
\text { spironolactone) }\end{array}$ & 1 & 1.5 \\
$\begin{array}{l}\text { Alpha 2 adrenergic receptor agonists (clonidine, } \\
\text { guanabenz, guanfacine, moxonidine) }\end{array}$ & 0 & 0.0 \\
\hline
\end{tabular}
*Multiple responses allowed 
Table 3: Social history and physical activity of the respondents $(n=68)$

\begin{tabular}{|c|c|c|}
\hline Variable & Frequency & Percentage $(\%)$ \\
\hline \multicolumn{3}{|l|}{ Do you smoke tobacco? } \\
\hline Yes & 4 & 5.9 \\
\hline Previously & 4 & 5.9 \\
\hline Never & 60 & 88.2 \\
\hline \multicolumn{3}{|c|}{$\begin{array}{l}\text { If yes, or previously to above, for how long? } \\
(\mathrm{n}=8)\end{array}$} \\
\hline $1-3$ years & 5 & 62.5 \\
\hline$>9$ years & 3 & 37.5 \\
\hline \multicolumn{3}{|l|}{ How many sticks per day? } \\
\hline $1-3$ & 6 & 75.0 \\
\hline $4-6$ & 2 & 25.0 \\
\hline \multicolumn{3}{|c|}{ Do you take alcoholic beverages drinks? } \\
\hline Yes & 14 & 20.6 \\
\hline Previously & 3 & 4.4 \\
\hline Never & 51 & 75.0 \\
\hline \multicolumn{3}{|c|}{$\begin{array}{l}\text { If yes or previously to above, for how long? } \\
(\mathrm{n}=17)\end{array}$} \\
\hline $1-3$ years & 7 & 41.2 \\
\hline $4-6$ years & 2 & 11.8 \\
\hline$>9$ years & 8 & 47.0 \\
\hline \multicolumn{3}{|l|}{ Quantify bottles per day $(n=17)$} \\
\hline $1-3$ & 17 & 100.0 \\
\hline \multicolumn{3}{|c|}{ Type of alcoholic beverage $(n=17)$} \\
\hline Alcohol & 13 & 76.5 \\
\hline Palm wine/other local beer & 4 & 23.5 \\
\hline \multicolumn{3}{|c|}{ What is the physical exercise you engage in? } \\
\hline None & 1 & 1.5 \\
\hline Brisk walking & 59 & 86.7 \\
\hline Jogging & 6 & 8.8 \\
\hline Cycling & 1 & 1.5 \\
\hline Swimming & 1 & 1.5 \\
\hline \multicolumn{3}{|c|}{$\begin{array}{l}\text { How frequently do you engage in the physical } \\
\text { exercise specified in above? }\end{array}$} \\
\hline Less than 15 minutes daily & 14 & 20.5 \\
\hline At least $15-30$ minutes daily & 38 & 55.8 \\
\hline 2 to 3 days weekly & 8 & 11.6 \\
\hline $4-5$ days weekly & 1 & 1.5 \\
\hline Everyday & 5 & 7.7 \\
\hline Occasionally & 2 & 2.9 \\
\hline
\end{tabular}

Table 4: Findings on physical examination of the respondents on the day of recruitment into the study $(n=67)$, Week 1

\begin{tabular}{lcc}
\hline Variable & Frequency & Percentage \\
\hline Blood pressure & & \\
Hypertensive & 18 & 26.8 \\
Normotensive & 49 & 73.2 \\
Weight & & \\
$30-50 \mathrm{~kg}$ & 2 & 3.0 \\
$51-70 \mathrm{~kg}$ & 26 & 38.8 \\
$71-90 \mathrm{~kg}$ & 30 & 44.8 \\
$>90 \mathrm{~kg}$ & 9 & 13.4 \\
Height & & \\
$1.41-1.6 \mathrm{~m}$ & 39 & 58.2 \\
$1.61-1.80$ m & 27 & 40.3 \\
$>1.80 \mathrm{~m}$ & 1 & 1.5 \\
Body Mass Index (BMI) & & \\
$18.5-24.9$ (healthy range) & 13 & 19.4 \\
$25-29.9$ (overweight) & 25 & 37.3 \\
$30-39.9$ (obese) & 25 & 37.3 \\
$\geq 40$ (morbidly obese) & 4 & 6.0 \\
\hline
\end{tabular}


Table 5: Findings on physical examination of the respondents in weeks following recruitment into the study $(n=67)$

\begin{tabular}{|c|c|c|}
\hline Variable & Frequency & Percentage \\
\hline \multicolumn{3}{|l|}{ Week 3} \\
\hline \multicolumn{3}{|l|}{ Blood pressure status $(n=67)$} \\
\hline Hypertensive & 19 & 28.4 \\
\hline Normotensive & 48 & 71.6 \\
\hline \multicolumn{3}{|l|}{ Body Mass Index (BMI) } \\
\hline $18.5-24.9$ (healthy weight range) & 13 & 19.4 \\
\hline $25-29.9$ overweight & 26 & 38.8 \\
\hline$>30-39.9$ obese & 25 & 36.8 \\
\hline$\geq 40$ (Morbid obesity) & 3 & 4.4 \\
\hline \multicolumn{3}{|l|}{ Week 5} \\
\hline \multicolumn{3}{|l|}{ Blood pressure status $(n=63)$} \\
\hline Hypertensive & 16 & 25.4 \\
\hline Normotensive & 47 & 74.6 \\
\hline \multicolumn{3}{|l|}{ BMI } \\
\hline $18.5-24.9$ (healthy weight range) & 11 & 17.5 \\
\hline $25-29.9$ overweight & 26 & 41.3 \\
\hline$>30-39.9$ obese & 23 & 36.5 \\
\hline$\geq 40$ (Morbid obesity) & 3 & 4.7 \\
\hline \multicolumn{3}{|l|}{ Week 7} \\
\hline \multicolumn{3}{|l|}{ Blood pressure status $(n=60)$} \\
\hline Hypertensive & 8 & 13.3 \\
\hline Normotensive & 52 & 86.7 \\
\hline \multicolumn{3}{|l|}{ BMI } \\
\hline $18.5-24.9$ (healthy weight range) & 11 & 17.5 \\
\hline $25-29.9$ overweight & 26 & 41.3 \\
\hline$>30-39.9$ obese & 23 & 36.5 \\
\hline$\geq 40$ (Morbid obesity) & 0 & 0.0 \\
\hline \multicolumn{3}{|l|}{$\begin{array}{l}\text { Week } 9 \\
\text { Blood pressure status }(n=60)\end{array}$} \\
\hline Hypertensive & 7 & 11.6 \\
\hline Normotensive & 53 & 88.4 \\
\hline \multicolumn{3}{|l|}{ BMI } \\
\hline $18.5-24.9$ (healthy weight range) & 12 & 20.0 \\
\hline $25-29.9$ overweight & 26 & 43.4 \\
\hline$>30-39.9$ obese & 22 & 36.6 \\
\hline$\geq 40$ (Morbid obesity) & 0 & 0.0 \\
\hline
\end{tabular}


Table 6: Cholesterol, triglicerides, hdl, ldl and glucose profile of respondents on the day of recruitment $(\mathrm{n}=67)$

\begin{tabular}{|c|c|c|c|}
\hline $\begin{array}{l}\text { Respondents' blood parameter } \\
(\mathrm{mmol} / \mathrm{L})\end{array}$ & Frequency (\%) & Mean & Std. Deviation \\
\hline $\begin{array}{l}\text { Total Cholesterol } \\
\text { Normal }(<5.2) \\
\text { Borderline }(5.2-6.2) \\
\text { High }(\geq 6.3)\end{array}$ & $\begin{array}{c}46(68.7 \%) \\
18(26.9 \%) \\
3(4.5 \%)\end{array}$ & 4.78 & 1.00 \\
\hline $\begin{array}{l}\text { Triglycerides } \\
\text { Normal }(\leq 1.7) \\
\text { Borderline }(1.8-2.4) \\
\text { High }(\geq 2.5)\end{array}$ & $\begin{array}{c}54(80.6 \%) \\
11(16.4 \%) \\
2(3.0 \%)\end{array}$ & 1.25 & 0.65 \\
\hline $\begin{array}{l}\text { HDL-C } \\
\text { Low }(<1.0) \\
\text { Normal }(1.0-1.6) \\
\operatorname{High}(\geq 1.7)\end{array}$ & $\begin{array}{c}38(56.7 \%) \\
21(31.3 \%) \\
8(11.9 \%)\end{array}$ & 1.05 & 0.56 \\
\hline $\begin{array}{l}\text { LDL-C } \\
\text { Normal (optimal/near optimal: }<3.4) \\
\text { Borderline }(3.4-4.1) \\
\text { High }(\geq 4.2)\end{array}$ & $\begin{array}{l}45(67.2 \%) \\
10(14.9 \%) \\
12(17.9 \%)\end{array}$ & 3.08 & 1.14 \\
\hline $\begin{array}{l}\text { Glucose (Random blood sugar) } \\
\text { Low }(<3.89) \\
\text { Normal }(\text { acceptable: } 3.89-11.0) \\
\text { High }(\geq 11.1)\end{array}$ & $\begin{aligned} & 3(4.5 \%) \\
62 & (92.5 \%) \\
1 & (1.5 \%)\end{aligned}$ & 5.59 & 1.31 \\
\hline
\end{tabular}

\section{CONCLUSION}

The study demonstrated that daily consumption of cocoa product in hypertensive patient may be associated with a slight reduction in blood pressure while having no significant effect on the BMI of individuals hence suggesting no significant increased risk of the development of weight-related pathologies.

\section{RECOMMENDATION}

Further studies need to be done on a larger scale to further substantiate the findings of this study and also evaluate the role of hypertension-related blood parameters (e.g. serum lipids) on the relationship between cocoa consumption and BP control.

\section{DISCLOSURE}

This work was supported by a grant from the Tertiary Educational Trust Fund (TETFUND) of the Federal Republic of Nigeria.

\section{ACKNOWLEDGEMENTS}

The authors acknowledge the healthcare givers working at both the LAUTECH Teaching hospital Medical Consultants Outpatient Department, ECG Laboratory as well as the General Outpatient Department.

\section{REFERENCES}

1. Assa A, Asriati DW, Indriana D, Sampebarra AL. Mineral contents in fermented bean shells of Forastero-cocoa (Theobroma cacao L) clones. ICP Conference Series Earth and Environmental Science 355:012108 DOI: $10.1088 / 1755-1315 / 1 / 012108$

2. Corti R, Flammer AJ, Hollenberg NK, Luscher TF. Cocoa and cardiovascular health. Circulation. 2009; 119: 1433-1441.

3. Lee Hooper, Colin Kay, Asmaa Abdelhamid, Paul A Kroon, Jeffrey S Cohn, Eric B Rimm et al. Effects of chocolate, cocoa, and flavan-3-ols on cardiovascular health: a systematic review and meta-analysis of randomized trials. Am J Clin Nutr. 2012; 95: 740751.

4. Jumar A, Schmieder R E. Cocoa Flavanol Cardiovascular Effects Beyond Blood Pressure Reduction. The Journal of Clinical Hypertension. 2016; 18 (4):352-8.

5. Kapoor S, Tyagi R, Saluja K, Chaturvedi A, Kapoor AK. Emerging health threats among a primitive tribal group of Central India. Journal of Public Health and Epidemiology. 2010;2: 13-19.

6. Katz DL, Doughty K, Ali A. Cocoa and Chocolate in Human Health and Disease. Antioxid Redox Signal. 2011; 15(10):2779-2811.

7. William C Knowler, Elizabeth Barrett-Connor, Sarah E Fowler, Richard F Hamman, John M Lachin, 
Elizabeth A Walker, et al. Diabetes Prevention Program Research Group. Reduction in the incidence of type 2 diabetes with lifestyle intervention or metformin, N Engl J Med, 2002;346:393-403.

8. Oladapo O. O. Falase A. O. Adedapo K. A prevalence of cardiometabolic risk factors among a rural Yoruba south-western population: a population-based survey. Cardiovasc J Afr. 2010; 21(1): 26-31.

9. Karin Ried, Thomas R Sullivan, Peter Fakler, Oliver R Frank, Nigel P Stocks. Effect of cocoa on blood pressure. Cochrane Database Syst Rev. 2012;(8): CD008893.

10. Taubert D, Roesen R, Lehmann C, et al. Effects of low habitual cocoa intake on blood pressure and bioactive nitric oxide: a randomized controlled trial. JAMA. 2007; 298: 49-60.

11. Wollgast J, Anklam E. Review on polyphenols in Theobroma cacao: changes in composition during the manufacture of chocolate and methodology for identification and quantification. Food Research International. 2000; 33(6):423-447.

12. Schroeter H, Heiss C, Balzer J, Kleinbongard P, Keen CL, Hollenberg NK et al. Epicatechin mediates beneficial effects of flavanol-rich cocoa on vascular function in humans. PNAS. 2006; 103(4):10241029. 